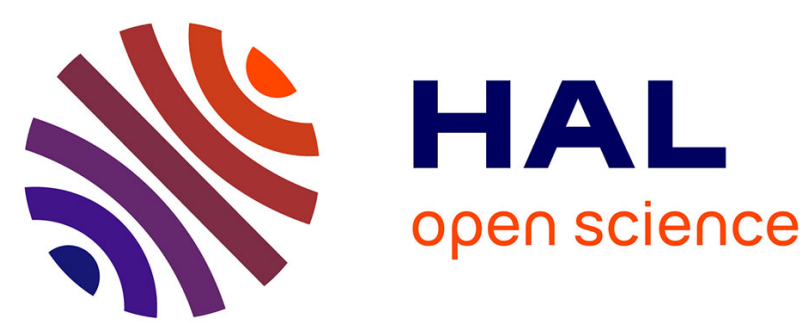

\title{
The fruit of Annona squamosa L. as a source of environmental neurotoxins: From quantification of squamocin to annotation of Annonaceous acetogenins by LC-MS/MS analysis
}

Natacha Bonneau, Lamia Baloul, Idensi Bajin Ba Ndob, François Senejoux, Pierre Champy

\section{To cite this version:}

Natacha Bonneau, Lamia Baloul, Idensi Bajin Ba Ndob, François Senejoux, Pierre Champy. The fruit of Annona squamosa L. as a source of environmental neurotoxins: From quantification of squamocin to annotation of Annonaceous acetogenins by LC-MS/MS analysis. Food Chemistry, 2017, 226, pp.32-40. 10.1016/j.foodchem.2017.01.042 . hal-01595662

\section{HAL Id: hal-01595662 \\ https://hal.science/hal-01595662}

Submitted on 26 Sep 2017

HAL is a multi-disciplinary open access archive for the deposit and dissemination of scientific research documents, whether they are published or not. The documents may come from teaching and research institutions in France or abroad, or from public or private research centers.
L'archive ouverte pluridisciplinaire HAL, est destinée au dépôt et à la diffusion de documents scientifiques de niveau recherche, publiés ou non, émanant des établissements d'enseignement et de recherche français ou étrangers, des laboratoires publics ou privés. 


\title{
The fruit of Annona squamosa L. as a source of environmental neurotoxins: From quantification of squamocin to annotation of Annonaceous acetogenins by LC-MS/MS analysis
}

\author{
Natacha Bonneau, Lamia Baloul, Idensi Bajin ba Ndob ${ }^{1}$, François Sénéjoux ${ }^{2}$, Pierre Champy ${ }^{*}$ \\ Laboratoire de Pharmacognosie, BioCIS, Univ. Paris-Sud, CNRS, Université Paris-Saclay, UFR Pharmacie, 5 rue J.-B. Clément, 92290 Châtenay-Malabry, France
}

\section{A R T I C L E I N F O}

\section{Article history:}

Received 21 July 2016

Received in revised form 17 November 2016

Accepted 10 January 2017

Available online 11 January 2017

\section{Keywords:}

Annona squamosa $\mathrm{L}$.

Annonaceous acetogenins

Annonacin

Atypical Parkinsonism

Bullatacin

HPLC-MS/MS

Squamocin

\begin{abstract}
A B S T R A C T
Annonaceous acetogenins (AAGs) are neurotoxins possibly responsible for atypical Parkinsonism/dementia clusters, via the consumption of edible Annonaceae fruits. Their presence was investigated in fruit pulps of Annona squamosa from different locations. Qualitative analysis of other AAGs was performed. We here report the identification of squamocin in batches from Asia, the Caribbean Basin and the Indian Ocean. This molecule was quantified by HPLC-UV, evidencing a content of $13.5-36.4 \mathrm{mg} /$ fruit. HPLC-ESI-Q-TOF allowed the detection of 25 different raw formulas matching with AAGs. LC-MS/MS methodological development was performed using 4 representative standards. The main AAGs could be annotated, including bullatacin (rolliniastatin-2) and annonacin. This study evidences a remarkable homogeneity for the main AAGs within the species, and discrepancies for minor compounds. These findings indicate that $A$. squamosa should be considered a risk factor for neurodegenerative disorders.
\end{abstract}

(c) 2017 Elsevier Ltd. All rights reserved.

\section{Introduction}

The consumption of Annona fruits and herbal teas has been linked to atypical forms of Parkinsonism/dementia in the French West Indies, as well as in other tropical areas (Caparros-Lefèbvre \& Elbaz, 1999; Caparros-Lefèbvre \& Steele, 2005; CaparrosLefèbvre et al., 2002; Lannuzel et al., 2007). Annonaceous acetogenins (AAGs) are lipophilic molecules of the Annonaceae family, with suspected involvement in the occurrence of these neurodegenerative diseases (Champy et al., 2008). To date, more than 450 AAGs have been described, all displaying homogeneous

\footnotetext{
Abbreviations: AAG, Annonaceous acetogenin; amu, atomic mass unit; CID, collision induced dissociation; EIC, extracted ion chromatogram; HPLC-ESI-Q-TOF, high performance liquid chromatograhy-electrospray-quadrupole-time of flight; HPLC-MS/MS, high-performance liquid chromatography-tandem mass spectrometry; HPLC-UV, high performance liquid chromatograhy-ultra violet detection; LCMS/MS, liquid chromatograhy-tandem mass spectrometry; LOD, limit of detection; LOQ limit of quantification; RSD, relative standard deviation; Rt, retention time; THF, tetrahydrofuran; TIC, total ion current.

* Corresponding author.

E-mail address: pierre.champy@u-psud.fr (P. Champy).

1 Present address: Institut de Pharmacopée et de Médecine Traditionnelles (IPHAMETRA), CENAREST, Libreville BP26641, Gabon.

2 Present address: Laboratoire de Pharmacognosie, Equipe ECREIN, UMR 1019 INRA-UDA, Faculté de Pharmacie, Université d'Auvergne, 28 Place Henri Dunant BP 38, 63001 Clermont-Ferrand Cedex, France.
}

structures (Bermejo et al., 2005). These molecules are generally constituted by 35 or 37 carbon atoms, with an oxygenated aliphatic chain bearing a terminal butyrolactone. Their classification, as established by Cavé and co-workers (Cavé, Cortes, Figadère, Laurens, \& Pettit, 1997), relies on their main structural features, with types depending on the number of THF rings on the aliphatic chain, and sub-types defined by the structure of the lactonic ring. They most commonly belong to the A-type (mono-THF AAGs) and to the B-type (adjacent bis-THF AAGs) structures. The main sub-types are the sub-type $1 \mathrm{a}$ for an $\alpha, \beta$-unsaturated $\gamma$-methyl- $\gamma$-lactone, and the sub-type $1 \mathrm{~b}$ in which this lactone is associated with a hydroxyl-group on the C-4 position. Since AAGs are potent inhibitors of mitochondrial complex I (NADH ubiquinone oxydo-reductase) in the respiratory chain, structure-activity relationships have been thoroughly explored for this target, showing a tendency towards higher potency for B-type and 1b sub-type structures (Bermejo et al., 2005). Interestingly, additional protein targets have been proposed using fluorescent analogues of the AAG squamocin (B-type, sub-type 1a), which displayed targeting towards the mitochondrial membrane (Derbré, Roué, Poupon, Susin, \& Hocquemiller, 2005; Derbré et al., 2008). Several AAGs, including squamocin, have been found to decrease ATP levels, to induce neuronal cell death and to cause tau protein redistribution in neuronal primary cultures (Höllerhage et al., 2009). Moreover, annonacin (A-type, sub-type 
1b), which has been identified as the main AAG in Annona muricata L. (soursop), proved to be neurotoxic in rodents and to trigger tau-pathology upon subchronic exposure (Champy et al., 2004; Yamada et al., 2014). Similar findings were observed in mice through dietary exposure to the fruit juice of $A$. muricata over a one-year period (Rottscholl et al., 2016). Since evidence of possible neurotoxic long-term effects in humans was brought to light, estimation of exposure to AAGs raised the attention of several research groups. Already largely described in leaves and other parts of Annona trees, AAGs have also been reported in the edible fruit pulps of $A$. muricata and Asimina triloba (L.) Dunal, along with quantitative estimations (Champy et al., 2005; Levine et al., 2015; Potts et al., 2012). AAG compositions of some Annona-derived food products have been described (Champy, Guérineau, \& Laprévote, 2009; Le Ven et al., 2012; Le Ven et al., 2014), evidencing mainly $\mathrm{C}_{35}$ AAGs for the species $A$. muricata and $A$. cherimolia. Squamocin is one of the main AAGs in Annona squamosa L. (Bermejo et al., 2005) and was reported in high amounts in the seeds of this species (Champy, 2011; Yang et al., 2009). The presence of AAGs in $A$. squamosa fruit pulp yielded scarce and limited reports (Bonneau et al., 2012; Champy et al., 2008; Hollerhage et al., 2015). Precise identification, unambiguous quantitative data and insight on possible variabilities are still acutely needed. In the present study the fruit pulp of $A$. squamosa was examined, using four batches from different cultivation areas, in order to confirm the presence of squamocin in A. squamosa pulp, and to describe the structural features of the other major AAGs, in a dereplicative approach. The identification of squamocin and its quantification using a robust method with the requisite validation are presented, as well as a methodological development by HPLC-MS/MS with post-column infusion of lithium (Le Ven et al., 2012), allowing an overview of the variety of AAGs in the batches studied, and details of the main representatives of this molecular series to be described.

\section{Material and methods}

\subsection{Chemical and reagents}

Standards (see Fig. 2) were isolated in-house (purity >97\%), under previously described conditions (Bermejo et al., 2005), from the seeds of Annona muricata L. for annonacin (1) and annonacinone (2), seeds of Annona bullata A. Rich. for bullatacin (3), and seeds of Annona squamosa L. for squamocin (4). Methylene chloride, methanol and acetonitrile (HPLC-grade) were supplied by CarloErba SDS (Val de Reuil, France). Lithium iodide (LiI) was provided by Sigma-Aldrich (St. Quentin Fallavier, France). Ultra-pure water was prepared in-house with a Millipore Milli-Q purification system (Darmstadt, Germany).

\subsection{Plant material}

Four distinct batches (A-D) of Annona squamosa L. ripe fruits were directly obtained from food retailers. Places of origin (country, region), of purchase and months of harvest, respectively, were: batch A: Thailand (4 fruits; Asian food store, France; January; $1062 \mathrm{~g}$ ); batch B: Mauritius (Indian Ocean; 1 fruit; local fruit market; March; $217 \mathrm{~g}$ ); batch C: Martinique (French West Indies; 1 fruit; local fruit market; March; $151 \mathrm{~g}$ ); batch D: Vietnam (4 fruits; Rungis market, France; February; $1003 \mathrm{~g}$ ). Fruit pulps (batch A: $741 \mathrm{~g}$; batch B: $123 \mathrm{~g}$; batch C: $80 \mathrm{~g}$; batch D: $601 \mathrm{~g}$; fresh pulp) were carefully separated from the seeds and pericarps, and then air-dried before powdering. Their water content comprised between 79 and $81 \%$.

\subsection{Crude extracts}

Dried pulp powders were subjected to 3 successive macerations of $3 \mathrm{~h}$ in distilled $\mathrm{CH}_{2} \mathrm{Cl}_{2}(10 \% \mathrm{~m} / \mathrm{v})$. Extractions were performed
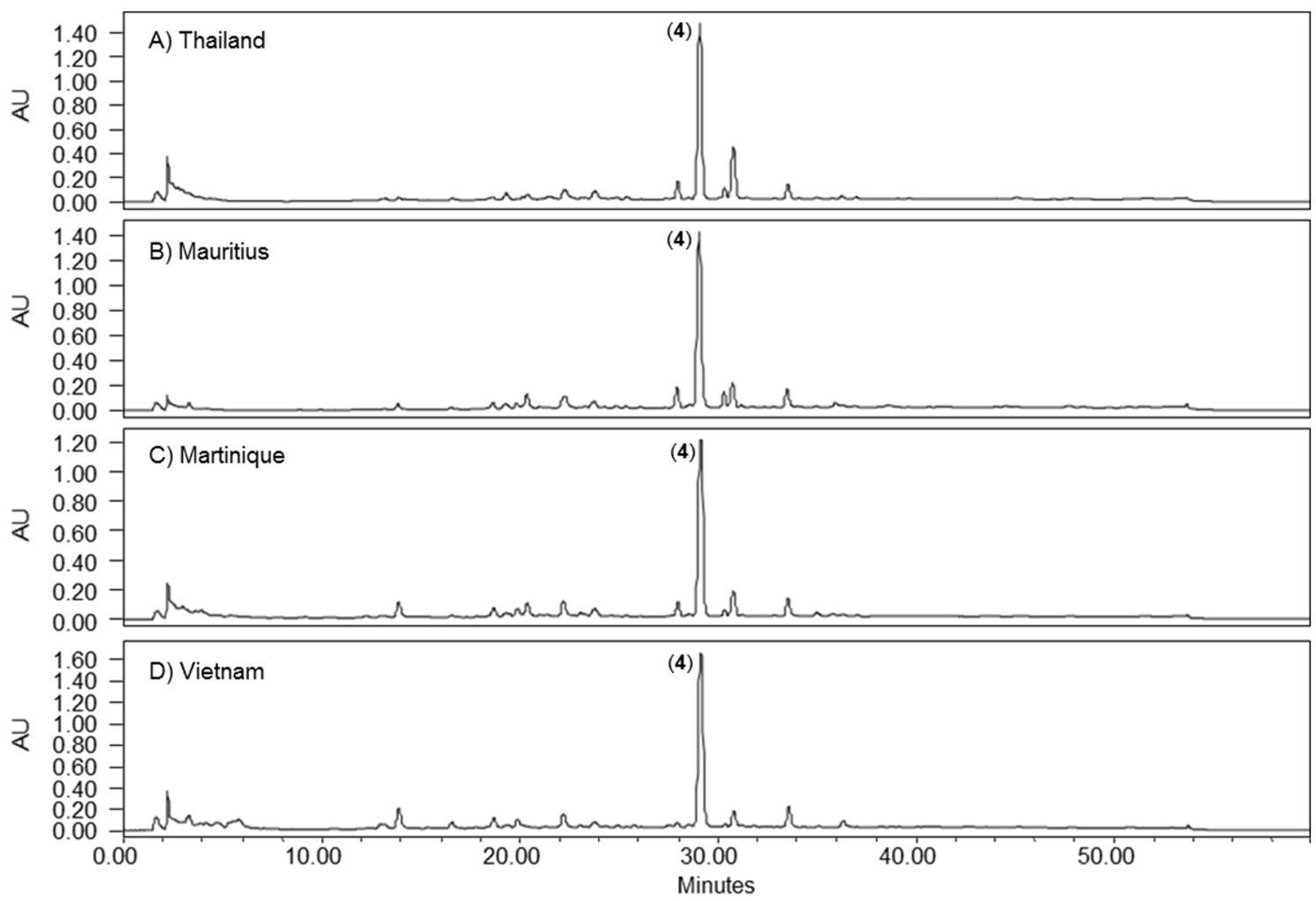

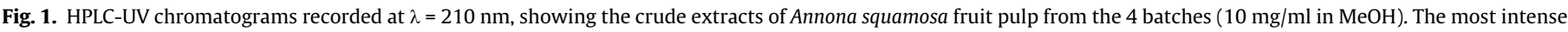
peak $(\mathrm{Rt}=29.0 \mathrm{~min})$ was identified as squamocin $(4)$. Quantitative data are presented in Supplementary Table S1. 


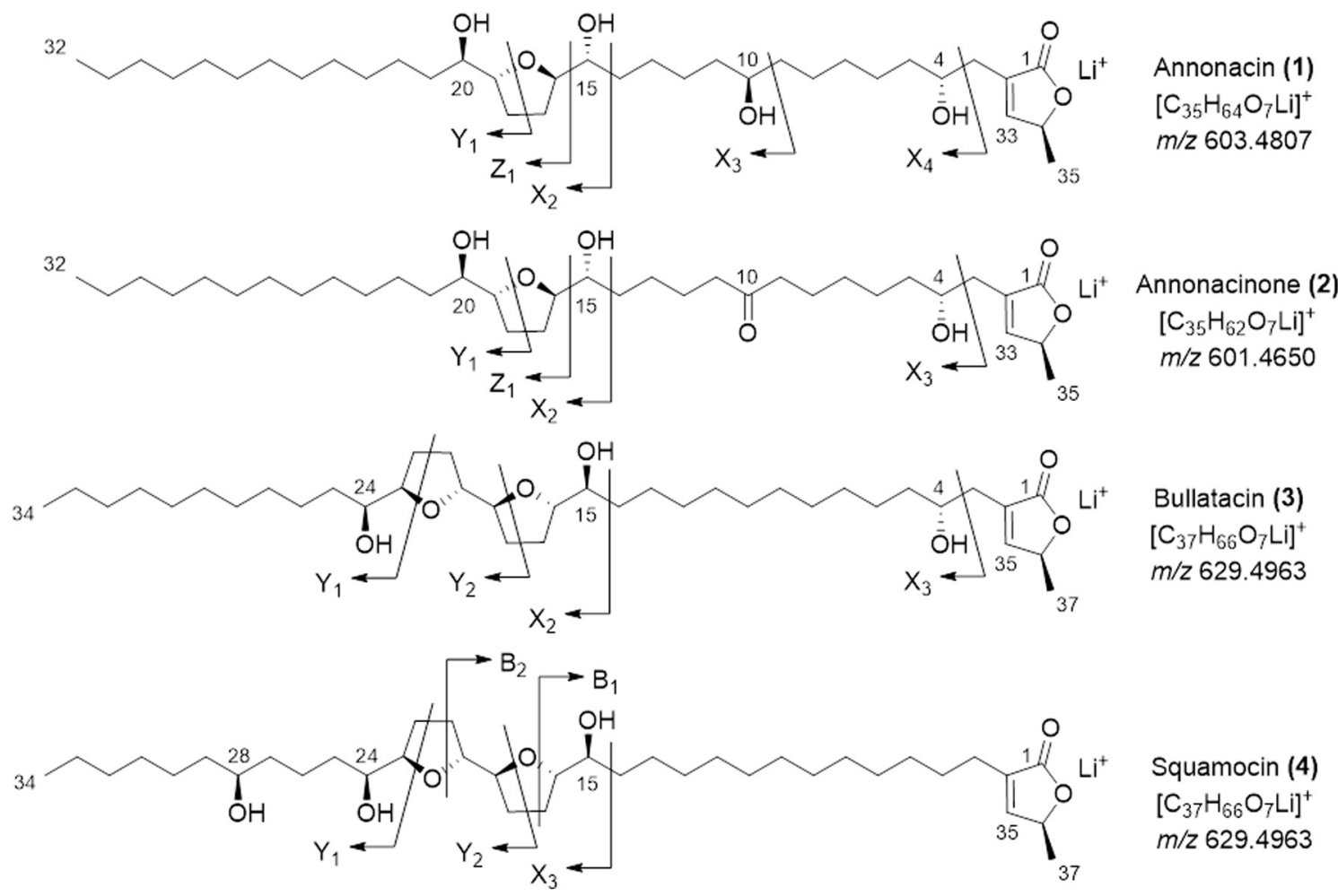

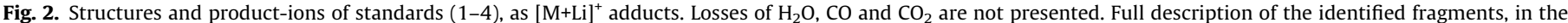
conditions used, is presented in Supplementary Tables S2-S5.

under agitation at room temperature, followed by filtration and reduction to dryness under reduced pressure in order to obtain crude extracts, with yields of 0.19 (batch A), 0.25 (batch B), 0.22 (batch $\mathrm{C}$ ) and $0.13 \%$ (batch $\mathrm{D}$ ) with regard to fresh material.

\subsection{Sample preparation and standards solutions}

Solutions of squamocin in methanol were prepared from $4 \cdot 2 \cdot 10^{-7}$ to $5.10^{-4} \mathrm{M}$ for LOQ and LOD determination, and at $5.10^{-6}, 1.10^{-5}, 5.10^{-5}, 1.10^{-4}$ and $5.10^{-4}, 1.10^{-3}$ and $1.5 .10^{-3} \mathrm{M}$ for the LC-UV calibration curve. Solutions of crude extracts were prepared at a concentration of $10 \mathrm{mg} / \mathrm{ml}$ in $\mathrm{MeOH}$ for LC-UV quantification. Five microliters of each solution were injected four times.

For LC-MS/MS annotation, stock solutions $(1 \mathrm{mg} / \mathrm{ml})$ of each standard were prepared in $\mathrm{MeOH}$ and stored at $4{ }^{\circ} \mathrm{C}$ until dilution for analysis. Solutions of crude extracts were prepared extemporaneously, at a concentration of $1 \mathrm{mg} / \mathrm{ml}$ in $\mathrm{MeOH}$. Injection volume was $5 \mu \mathrm{l}$. Analysis were performed twice.

\subsection{Chromatographic conditions}

\subsubsection{Quantification by HPLC-UV and co-injection with squamocin}

Quantification was performed by HPLC-UV recorded at $\lambda=210 \mathrm{~nm}$. The analytical HPLC apparatus (Waters) was composed of an autosampler 717 plus, a 1525 binary pump and a 2996 photodiode array detector. Data treatment was performed with Empower Pro ${ }^{\circledR}$ software (2002 Waters Corporation). A C18 Sunfire ${ }^{\circledR}$ Waters column $(2.1 \times 100 \mathrm{~mm}, 3.5 \mu \mathrm{m})$ was used, fitted with the corresponding C18 Sunfire ${ }^{\circledR}$ Waters pre-column. The column temperature was set at $30^{\circ} \mathrm{C}$. The mobile phase consisted of a water (A)/acetonitrile (B) gradient (A/B 60:40 $\rightarrow$ 0:100 in $25 \mathrm{~min}$ ) followed by $15 \mathrm{~min} 100 \% \mathrm{~B}$ washing. The flow-rate was $0.3 \mathrm{ml}$. $\min ^{-1}$. Squamocin (4) was co-injected with pulp extract (see
Supplementary Fig. S1). A C18 Sunfire ${ }^{\circledR}$ Waters $(4.6 \times 150 \mathrm{~mm}$, $5 \mu \mathrm{m})$ Waters column, fitted with the corresponding C18 Sunfire ${ }^{\circledR}$ Waters pre-column was used. Elution conditions were similar except for a flow-rate of $1 \mathrm{ml} \cdot \mathrm{min}^{-1}$.

2.5.2. Annotation by HPLC-MS/MS and co-injection with squamocin

An Agilent Technologies 1260 infinity HPLC chain with DAD detection and linked to a 6530 Accurate-Mass Q-TOF LC/MS equipped with a dual-ESI source was used, in positive mode. The instrument was used in its extended dynamic range mode $(2 \mathrm{GHz})$ with low mass range $(1700 \mathrm{mz})$. A C18 Sunfire ${ }^{\circledR}$ Waters column $(2.1 \times 100 \mathrm{~mm}, 3.5 \mu \mathrm{m})$ was used, fitted with the corresponding C18 Sunfire ${ }^{\circledR}$ Waters pre-column. The column temperature was set at $30^{\circ} \mathrm{C}$. The mobile phase consisted of a water $(A) /$ acetonitrile $(B)$ gradient $(A / B$ 60:40 $\rightarrow 0: 100$ in 25 min) followed by 9 min $100 \%$ B washing. The flow-rate was $0.25 \mathrm{ml}$. $\mathrm{min}^{-1}$. UV detection was performed at $\lambda=210 \mathrm{~nm}$. Purine $\mathrm{C}_{5} \mathrm{H}_{4} \mathrm{~N}_{4}[\mathrm{M}+\mathrm{H}]^{+}$ion $(\mathrm{m} / \mathrm{z} 121.050873)$ and hexakis $(1 \mathrm{H}, 1 \mathrm{H}$ $3 \mathrm{H}$-tetrafluoropropoxy) phosphazine) $\mathrm{C}_{18} \mathrm{H}_{18} \mathrm{~F}_{24} \mathrm{~N}_{3} \mathrm{O}_{6} \mathrm{P}_{3} \quad[\mathrm{M}+\mathrm{H}]^{+}$ ion $(m / z$ 922.009798) were used as internal lock masses. The fragmentor was set at $180 \mathrm{~V}$. Source parameters were optimized for detection: the gas temperature was set at $325^{\circ} \mathrm{C}$, drying gas was $10 \mathrm{~L} / \mathrm{min}$, nebulizer was set at $35 \mathrm{psi}$ and Vcap was $4000 \mathrm{~V}$. Full scans were acquired with a resolution of 12000 (at $\mathrm{m} / z$ 922).

In targeted MS/MS mode, there were 2 scans events: acquisition was performed within the mass range $m / z 100-1000$ at a rate of 1 spectra/s, followed by an MS/MS scan, at a rate of 1 spectra/s. Fixed collision energies of $10,20,30,40,50$ or $70 \mathrm{eV}$ were used in successive runs. The targeted masses were $m / z 629.4963$ and 603.4807. The isolation width was 4 amu.

In auto-MS/MS mode, there were four scan events: acquisition was performed within the mass range $m / z 100-1000$ at a rate of 1 spectra/s, followed by MS/MS scans on the 3 most intense ions at a rate of 3 spectra/s. The minimum intensity for the precursor 
ion was 10,000 counts. Precursor ions were placed on an exclusion list after 3 spectra acquired in MS/MS scan, and released after $0.2 \mathrm{~min}$. The isolation width was $4 \mathrm{amu}$. Lil salt, known as a signal enhancer producing valuable fragmentation for AAGs (Le Ven et al., 2012) was infused post-column, at a concentration of $2 \mathrm{mM}$ in $\mathrm{MeOH}$ and a flow-rate of $5 \mu \mathrm{l} / \mathrm{min}$.

\subsection{Data interpretation}

AAGs displayed very high $[\mathrm{M}+\mathrm{Li}]^{+}$ions compared to $[\mathrm{M}+\mathrm{H}]^{+}$ adducts, under the working conditions used for lithium infusion. Thus, only $[\mathrm{M}+\mathrm{Li}]^{+}$adducts were considered, $[\mathrm{M}+\mathrm{H}]^{+}$adducts being mostly undected. Since AAGs have very homogeneous structures, we delimited a range of typical raw formulas corresponding to their most common structural features (Bermejo et al., 2005), i.e. a $C_{32}$ or $C_{34}$ alkyl backbone bearing an $\alpha, \beta$-unsaturated- $\gamma$-methy l-butyrolactone (sub-type 1), yielding the two basal formulas $\mathrm{C}_{35} \mathrm{H}_{66} \mathrm{O}_{2}$ and $\mathrm{C}_{37} \mathrm{H}_{70} \mathrm{O}_{2}$. Oxygenated alkyl-chains with varying degrees of unsaturation were considered, starting from these basal formulas. By the addition of 1 to 8 oxygen atoms and of 0 to 3 double bond equivalents (DBE), the following intervals were obtained for $\mathrm{C}_{35}$ AAGs: $\left[\mathrm{C}_{35} \mathrm{H}_{60} \mathrm{O}_{3}+\mathrm{Li}\right]^{+}(535.4697 \mathrm{amu})$ to $\left[\mathrm{C}_{35} \mathrm{H}_{66} \mathrm{O}_{10}+\mathrm{Li}\right]^{+}$ $(653.4811 \mathrm{amu})$. Similarly, the following intervals were considered for $\mathrm{C}_{37}$ AAGs: $\left[\mathrm{C}_{37} \mathrm{H}_{64} \mathrm{O}_{3}+\mathrm{Li}\right]^{+}(563.5010 \mathrm{amu})$ to $\left[\mathrm{C}_{37} \mathrm{H}_{70} \mathrm{O}_{10}+\mathrm{Li}\right]^{+}$ (681.5124 amu). These ranges comprised all formulas of the most largely described and commonly found AAGs (Bermejo et al., 2005; Le Ven et al., 2012). Extracted ion chromatograms (EIC) $(m /$ $z \pm 2.5 \mathrm{ppm}$ ) were obtained for each pulp. For the major hits retrieved, the presence of 1 to 2 acetyl groups $\left(+\mathrm{CH}_{2} \mathrm{CO}\right.$, i.e. +42.0106 amu each) was investigated, following the same principle. A blank injection performed after injection of a crude extract in order to estimate carry-over resulted in an intensity of $10^{3}$ for the most prominent traces. Only traces yielding intensity $>10^{4}$ were then considered as being significant (see Supplementary information). Structural characterization of the major compounds was performed by targeted MS/MS: a characteristic pattern comprising losses of $\mathrm{CO}, \mathrm{CO}_{2}$ and $\mathrm{H}_{2} \mathrm{O}$ from the molecular ions, confirmed targeted compounds as being AAGs (Allegrand et al., 2010). For assignment of the structural features of targeted AAGs, the nomenclature established by Laprévote and Das (1994) for the fragmentation of AAGs was used: Fragments containing the terminal lactonic ring were designated $\mathrm{A}, \mathrm{B}, \mathrm{C}$ and $\mathrm{D}$; Those containing the terminal $\mathrm{CH}_{3}$ were named $\mathrm{W}, \mathrm{X}, \mathrm{Y}$ and $\mathrm{Z}$ (e.g. disruptions in $\alpha$-positions of an hydroxyl group yield $A$ and $X$ fragments; see Allegrand et al., 2010 and Le Ven et al., 2012; Fig. 2).

\section{Results and discussion}

\subsection{Detection and quantification of squamocin}

Four distinct batches of dried fruit pulp of $A$. squamosa were subjected to successive extractions with $\mathrm{CH}_{2} \mathrm{Cl}_{2}$, a solvent suitable for the retrieval of AAGs (Bermejo et al., 2005). The four extracts were analyzed by HPLC-UV. Profiles obtained at $\lambda=210 \mathrm{~nm}$ appeared similar, with one prominent peak showing a $\lambda_{\max }$ of $210 \mathrm{~nm}$, at Rt $=29.1 \mathrm{~min}$ under the conditions used (Fig. 1). Retention time and HPLC-MS/MS analysis (see Sections 3.2,3.3) suggested this compound to be squamocin (4), which was described as the main AAG in the seeds of the species (Champy, 2011). Its identity was confirmed by co-injection of purified squamocin (4) with batch A in HPLC-UV (Supplementary Fig. S1), then in HPLCMS (Supplementary Figs. S2 and S3). In order to quantify this compound, HPLC-UV determination at $\lambda=210 \mathrm{~nm}$ appeared suitable, as a clean baseline easily allowed integration of the corresponding peak. The limit of detection (LOD) was established as the concen- tration displaying a chromatographic peak with a signal/noise ratio $>3$. The limit of quantification (LOQ) was defined as a signal/noise ratio $>10$ with an RSD of 4 repeated injections $<15 \%$. The LOD for squamocin (4) was $4 \cdot 2 \cdot 10^{-7} \mathrm{M}$ and the LOQ was $8.4 .10^{-7}$ M. A calibration curve, built by linear regression of the absorbance at $210 \mathrm{~nm}(y)$ against squamocin (4) concentration in $\mathrm{M}(\mathrm{x})$, was established between $5 \cdot 10^{-6}$ to $1.5 \cdot 10^{-3} \mathrm{M}$ and showed a suitable range of linearity $\left(R^{2}=0.999\right)$. The amount of squamocin (4) ranged from 13.5 to $36.4 \mathrm{mg}$ per fruit, i.e. approximately 180 to $260 \mathrm{mg} / \mathrm{kg}$ of fresh pulp (See Table S1). AAGs have previously been described in the fruits and derived-food products of several Annona species (Hollerhage et al., 2015; Le Ven et al., 2012, 2014). However, this is the first quantitative determination of AAGs in the fruit pulp of Annona squamosa. Indeed, a recently published estimation did not directly relate to fruit content (Hollerhage et al., 2015). An important variation was observed, possibly due to varieties, cultivation conditions or harvest time (Gu et al., 1999).

\subsection{MS/MS method development}

AAGs are present as complex mixtures in Annonaceae (Bermejo et al., 2005; Gromek, Hocquemiller, \& Cavé, 1994; Le Ven et al., 2012). Nevertheless, minor peaks could be observed, beside $\mathbf{4}$, on the UV chromatograms at $210 \mathrm{~nm}$, in all of the A. squamosa batches studied. After quantification of the main AAG, a more thorough description of the overall composition in other AAGs for each batch appeared necessary. A hyphenated technique was then used, coupling HPLC with an ESI-Q-TOF mass spectrometer, which allows precise mass measurements of both parent and product-ions and offers access to informative fragments. Fragmentation optimization was performed first, in order to adapt our previous method with an LTQ-Orbitrap ${ }^{\circledR}$ (Le Ven et al., 2012) to this different type of MS/MS apparatus, more routinely used in control and phytochemistry laboratories. Indeed, differences in generation of fragments and in their relative intensities is reported, depending on the type of spectrometer and fragmentation energy (Allegrand et al., 2010; Le Ven et al., 2012). Towards this aim, representative AAGs standards were chosen, that belonged to the most commonly encountered types and sub-types (1-4; Fig. 2). The aim is to differentiate the number and arrangement of THF cycles on the alkyl chain (e.g. A-type, B-type), and the absence or presence of a hydroxyl group in position 4 (sub-types $1 \mathrm{a}, 1 \mathrm{~b}$ ), which are known to produce characteristic fragments in the presence of lithium. The number and positions of the hydroxyl groups and the size of the alkyl spacer between the lactone and THF cycles are of importance as well, as they also influence the complex I inhibitory and neurotoxic potential of AAGs (Bermejo et al., 2005; Höllerhage et al., 2009). Fragmentation experiments were therefore conducted, under chromatographic conditions.

Targeted fragmentation was first used to compare product ions obtained from purified annonacin (1) (A-type, sub-type 1b) and squamocin (4) (B-type, sub-type 1a). Both standards were submitted to collision induced dissociation (CID) at a concentration of $100 \mathrm{ng} / \mathrm{ml}$, with 5 collision energies of $10,20,30,40$ and $50 \mathrm{eV}$ (Supplementary Fig. S4). The energy $50 \mathrm{eV}$ displayed the highest absolute and relative abundance for product-ions of informational value, in regard to the determination of types and sub-types. However, under these conditions, some of the expected fragments were missing. Comparative CID was then performed at 50 and $70 \mathrm{eV}$, at the concentrations 10 and $100 \mu \mathrm{g} / \mathrm{ml}$ for both 1 and 4, injected twice in order to assess the repeatability of fragmentation. Fragment abundances were about 3-7 times higher at $70 \mathrm{eV}$ for each replicate of the 2 tested concentrations (Supplementary Fig. S5). The collision energy of $70 \mathrm{eV}$ was therefore chosen for further analysis, with good repeatability at $10 \mu \mathrm{g} / \mathrm{ml}$ (Fig. 3). 


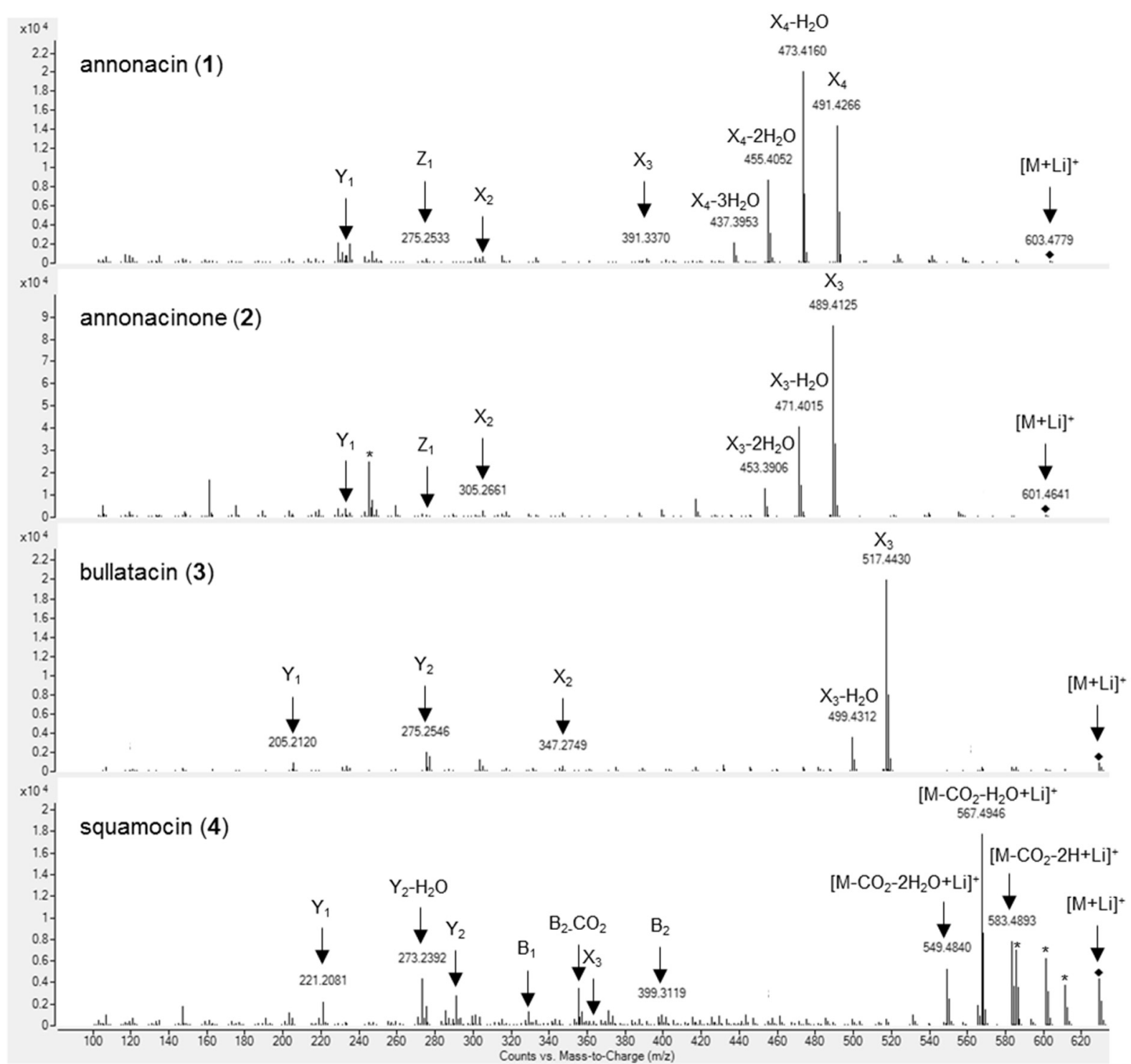

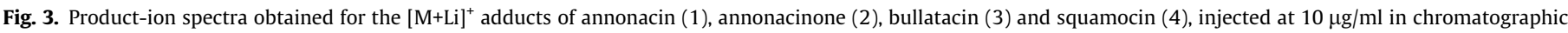

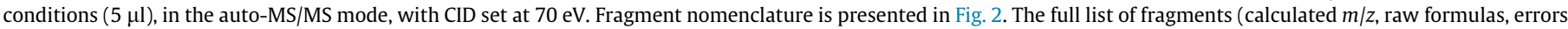
on mass measurement, intensity), including those marked by ( ${ }^{*}$ ), is provided in Supplementary Tables S2-S5.

Using the same collision energy and concentration, the autoMS/MS mode, tested with four standards $(\mathbf{1}, \mathbf{4}$, annonacinone (2) bullatacin (3), offered fully informative spectra: AAGs of sub-type 1b (1-3) yielded the corresponding X4 (or X3, depending on the number of hydroxyls) fragment. AAGs belonging to the A-type (1, 2) yielded $Y 1, Z 1$ and $X 2$ ions, while those of the B-type $(\mathbf{3}, \mathbf{4})$ gave $\mathrm{Y} 1, \mathrm{Y} 2$ and $\mathrm{X} 2$ (or $\mathrm{X} 3$ depending on the number of $\mathrm{C}$ terminal hydroxyls) fragments (Fig. 2). Worth noting is that B1 and B2 ions could be observed for squamocin (4) (sub-type 1a) but not for bullatacin (3) (sub-type 1b) (Fig. 3, Supplementary Tables S2-S5). These patterns are quite different from those observed with LTQOrbitrap ${ }^{\circledR}$. Finally, hydroxyl groups located on the $\mathrm{CH}_{3}$ terminal part of AAGs could not be located, as previously reported (Allegrand et al., 2010).

In order to gain insight into the LOD for informative fragments with an error inferior to $10 \mathrm{ppm}$, squamocin (4) was injected in concentrations ranging from 0.01 to $10 \mu \mathrm{g} / \mathrm{ml}$. At the concentration $0.1 \mu \mathrm{g} / \mathrm{ml}$, only its sub-type could be determined (see Supplementary Fig. S4). At $1 \mu \mathrm{g} / \mathrm{ml}$, each of the informative fragments described at higher concentrations was detected (Supplementary Table S5). The LOD of fragments necessary for the determination of AAGs bearing similar characteristics was therefore considered to be $1 \mu \mathrm{g} / \mathrm{ml}$. This appears to be a suitable limit for the analysis of crude extracts, at the concentration used $(1 \mathrm{mg} / \mathrm{ml})$, in the auto-MS/MS mode, as exemplified in Section 3.3.

\subsection{Qualitative analysis of AAGs and annotation}

Molecular formulas matching with AAGs were then searched in order to go deeper into the composition of the pulp crude extracts of $A$. squamosa (see Section 2.6). Twenty-five molecular formulas corresponding to AAGs were identified in at least one of the four batches, ten of which were present in every batch (Supplementary Table S6). Among these, the 7 most intense series of parent ions were investigated by targeted ( $m / z$ 629.4963) or auto-MS/MS, in order to highlight the common features of the fruit, independently of its origin. As expected, these molecules all showed the characteristic fragments of AAGs belonging to sub-type 1 . The major 


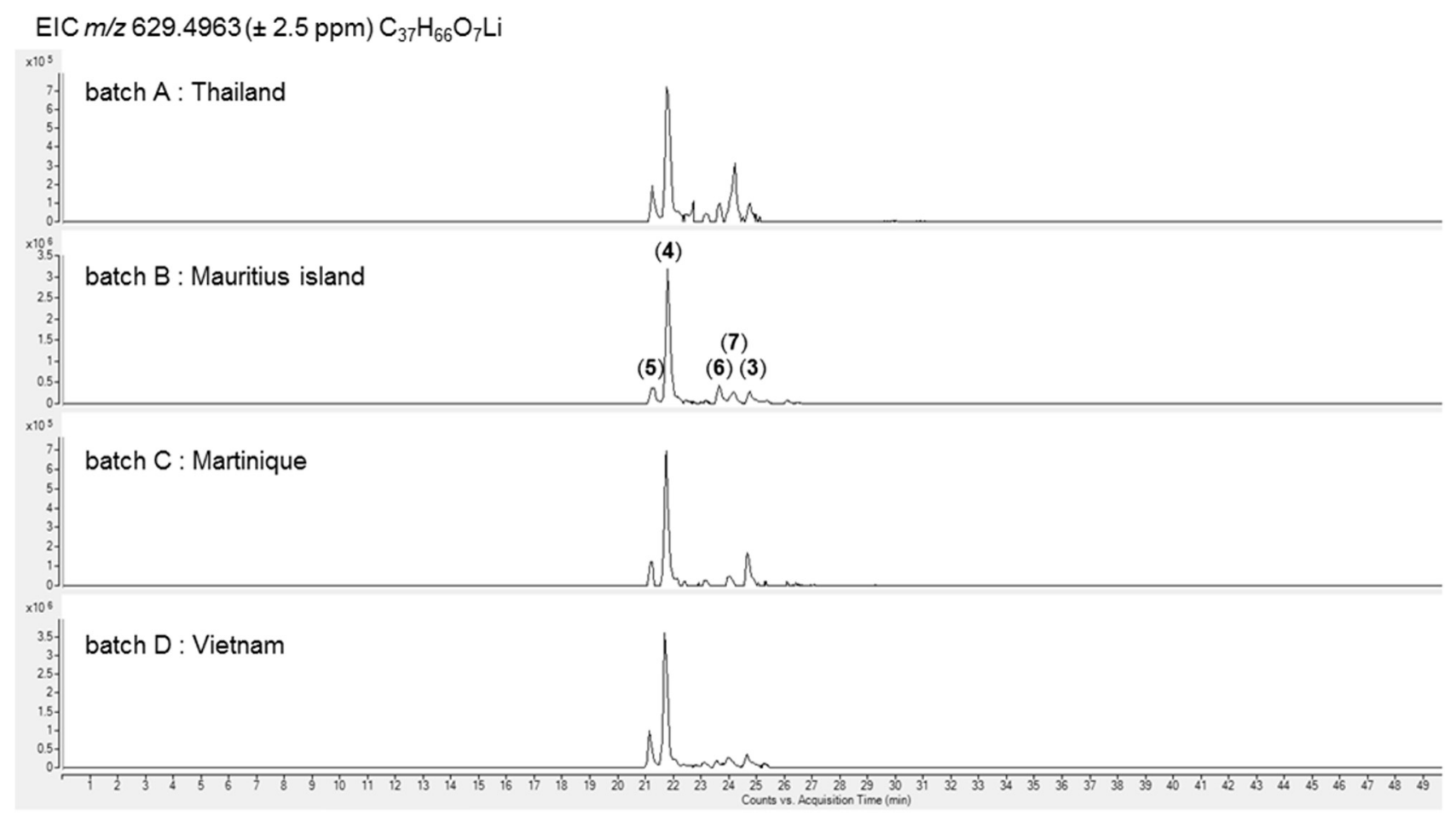

Fig. 4. Extracted ion chromatograms of $m / z 629.4963\left( \pm 2.5 \mathrm{ppm} ; \mathrm{C}_{37} \mathrm{H}_{66} \mathrm{O}_{7} \mathrm{Li}\right.$ ) from the four pulp crude extracts of $A$. squamosa.

AAGs for each of these 7 molecular formulas could be fully annotated, despite low intensity of parent ions and problems arising from co-elutions in several cases. Extracted ion chromatograms of $\mathrm{m} / \mathrm{z}$ 629.4963, corresponding to the $[\mathrm{M}+\mathrm{Li}]^{+}$adduct of $\mathrm{C}_{37} \mathrm{H}_{66} \mathrm{O}_{7}$, were the highest in the four batches, all showing 5 main peaks (Fig. 4) which were identified as follows: at Rt 21.2 (5) $\mathrm{min}$, an isomer of squamocin; at Rt 21.7 min, squamocin (4) itself, as previously confirmed by co-injection of the standard with batch A (See Section 3.1, Supplementary Fig. S2); at Rt $23.7 \mathrm{~min}$ (6) and Rt 24.2 min (7), bullatacin diastereoisomers; at Rt $24.8 \mathrm{~min}$; bullatacin (3) itself (Figs. 4 and 5). In this series, the relative amounts of the less abundant AAGs (5-7) appear variable, depending on the geographical origin.

Annotation of the AAGs $\mathbf{1}$ and 8-12 (Fig. 6), which gave the most intense $[\mathrm{M}+\mathrm{Li}]^{+}$adducts for the 6 other molecular formulas found in every batch, was performed based on the product-ion spectra obtained by auto-MS/MS (EIC are depicted in Supplementary Figs. S6-S12; the lists of detected informative fragments are presented in Supplementary Tables S12-S17). Among them, five AAGs with 35 carbon atoms could be annotated, 2 of them belonging to the A-type/sub-type 1a, another one to the A-type/sub-type $1 \mathrm{~b}$, which was identified as being annonacin (1; Rt $23.3 \mathrm{~min}$ ), and 2 to the B-type/sub-type 1a. Finally, minor mono- and di-acetylated derivatives might also have been present, but could not be characterized due to low intensity (Supplementary Table S6).

Interestingly, although the highest ionic abundance relies on the $\mathrm{C}_{37} \mathrm{H}_{66} \mathrm{O}_{7}$ AAGs, mainly due to squamocin (4), only two other molecular formula corresponding to $\mathrm{C}_{37} \mathrm{AAGs}$ are present in all of the batches studied, and can be hypothesized as being characteristic of $A$. squamosa (e.g. 12). The description presented here is not exhaustive but still conforms to the following metabolic trends for the species, reminiscent with observations in seeds (Bermejo et al., 2005; Champy, 2011): in the four batches of A. squamosa pulp, the AAGs displaying the highest intensity belong to the B-type and to sub-type $1 \mathrm{a}$, with 1 or 2 free-hydroxyls along the alkyl chain, and with an alkyl spacer of 13 carbon atoms between the lactone and THF cycles. These observations are worth comparing with known structure-activity relationships of AAGs (Höllerhage et al., 2009), suggesting a neurotoxic potential superior to that of the totum of $A$. muricata L., which mostly contains annonacin along with A1b and A1a AAGs (Champy et al., 2005, 2009; Le Ven et al., 2012).

\section{Conclusion}

This is the first quantitative determination of AAGs in the fruit pulp of Annona squamosa. The main AAG is squamocin (4), like in the other parts of the plant (Bermejo et al., 2005; Champy, 2011). This compound was quantified in four batches from distinct origins using HPLC-UV, chosen as a robust method (Gromek et al., 1994; Yang et al., 2009). HPLC-MS evidenced striking disparities in the AAG profile of the batches. However identical major AAGs, apparently constituting the core composition of the species, were identified and could be annotated.

If the exposure to AAGs here appears lower than for A. muricata, and despite the low bioavailability recently evidenced for an AAG (Bonneau, Schmitz-Afonso, Brunelle, Touboul, \& Champy, 2015), the consumption of the fruit of $A$. squamosa should be considered a risk factor for neurodegenerative disorders. Global estimation of the phytochemical, biological and epidemiological levels is still warranted, according to the overall chemical homogeneity evidenced here, and to the variety of structures identified in this work. 


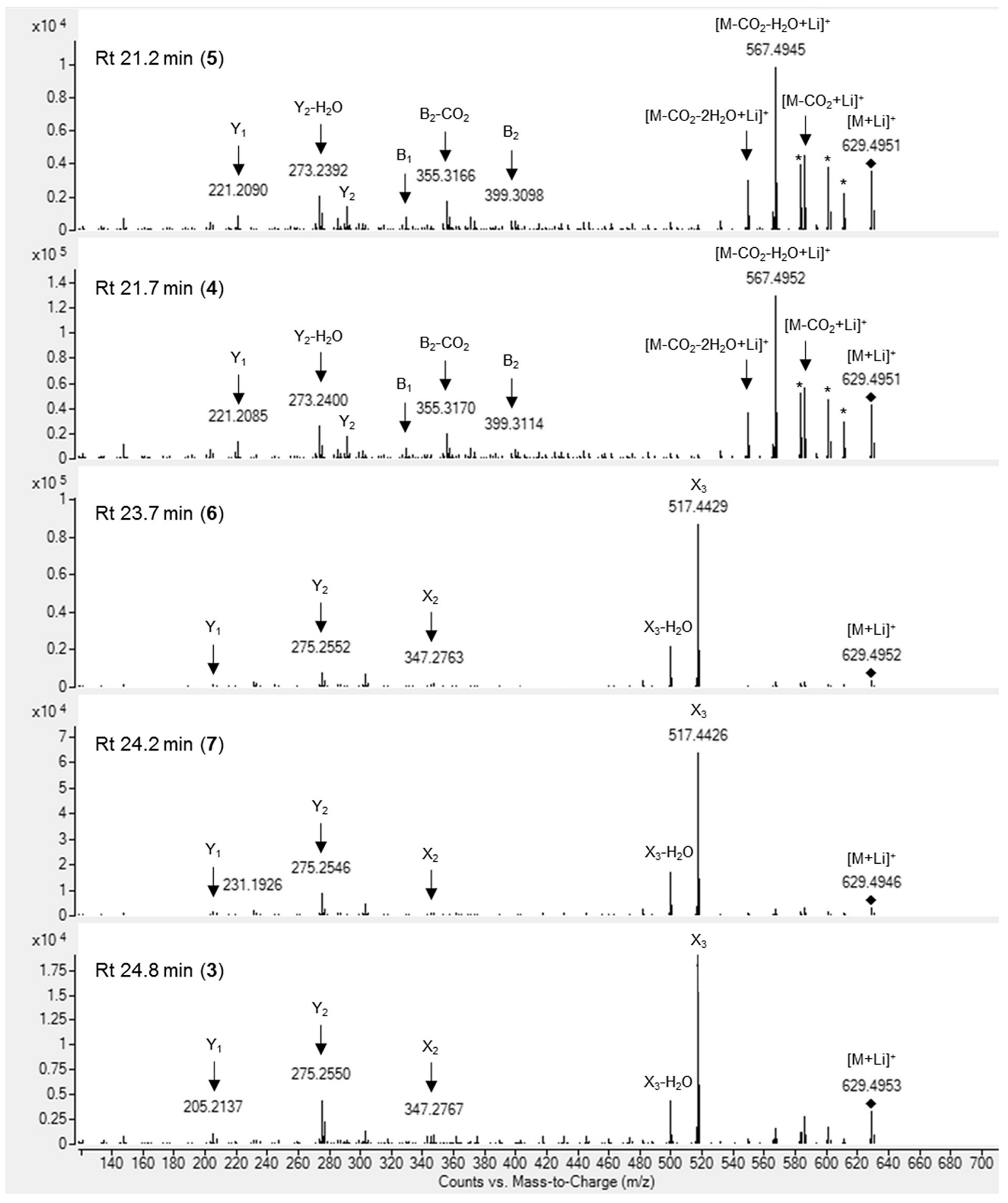

Fig. 5. Product-ion spectra from the major AAGs $\mathrm{C}_{37} \mathrm{H}_{66} \mathrm{O}_{7} \mathrm{Li}$ annotated (3-7). The full list of observed fragments (calculated $m / z$, raw formula, error of mass measurement, relative intensity) is provided in Supplementary Tables S7-S11. 


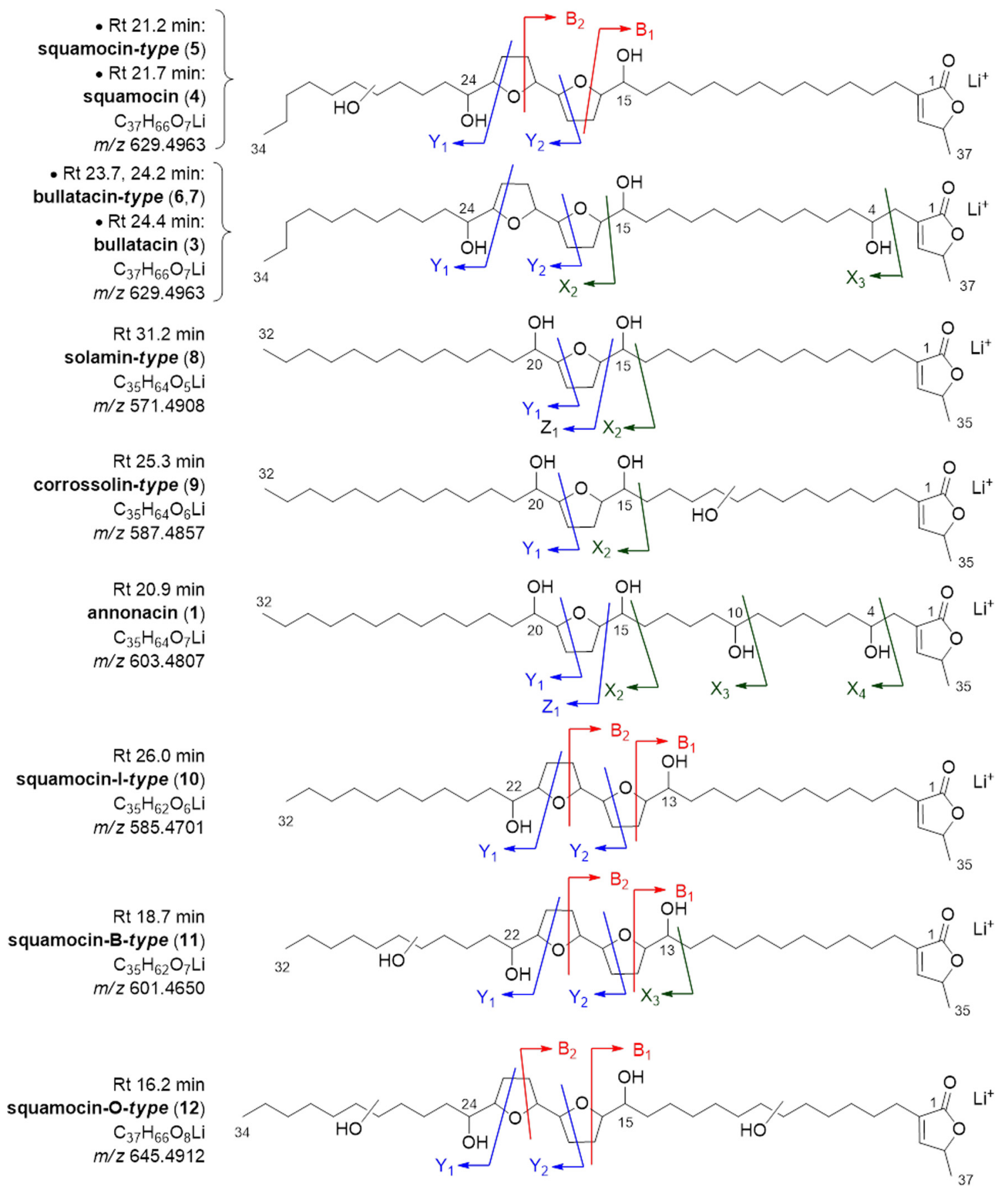

Fig. 6. Structures of the $C_{35}$ and $C_{37}$ annotated AAGs (1,3-12).Full description of the identified fragments is presented in Supplementary Tables S7-S17. The choice of examples relies on previous isolations from the species (Bermejo et al., 2005).

\section{Acknowledgements}

The authors are grateful to Dr David Touboul, Isabelle-SchmitzAfonso (ICSN-CNRS), Dr Marie Mejean and Karine Leblanc for fruitful discussions and guidance, and to Estella Vallade for technical assistance. Natacha Bonneau is the recipient of a doctoral grant from the Ministère de l'enseignement supérieur et de la recherche (France).

\section{Appendix A. Supplementary data}

Supplementary data associated with this article can be found, in the online version, at http://dx.doi.org/10.1016/j.foodchem.2017. 01.042 .

\section{References}

Allegrand, J., Touboul, D., Schmitz-Afonso, I., Guérineau, V., Giuliani, A., Le Ven, J., et al. (2010). Structural study of acetogenins by tandem mass spectrometry under high and low collision energy. Rapid Communications in Mass Spectrometry, 24, 3602-3608.

Bermejo, A., Figadère, B., Zafra-Polo, M. C., Barrachina, I., Estornell, E., \& Cortes, D. (2005). Acetogenins from Annonaceae: Recent progress in isolation, synthesis and mechanisms of action. Natural Products Reports, 22, 269-303.

Bonneau, N., Le Ven, J Schmitz-Afonso, I, Guérineau, V., Bajin ba Ndob, I., Baloul, L., et al. (2012). Annonaceous acetogenins as environmental neurotoxins: Human exposure from edible Annona fruits. Planta Medica, 78, PH25.

Bonneau, N., Schmitz-Afonso, I., Brunelle, A., Touboul, D., \& Champy, P. (2015). Method development for quantification of the environmental neurotoxin annonacin in Rat plasma by UPLC-MS/MS and application to a pharmacokinetic study. Journal of Chromatography B, 1004, 46-52. 
Caparros-Lefèbvre, D., \& Elbaz, A. (1999). Possible relation of atypical parkinsonism in the French West Indies with consumption of tropical plants: A case-control study. The Lancet, 354, 281-286.

Caparros-Lefèbvre, D., Sergeant, N., Lees, A., Camuzat, A., Daniel, S., Lannuzel, A., et al. (2002). Guadeloupean parkinsonism: A cluster of progressive supranuclear palsy-like tauopathy. Brain, 125, 801-811.

Caparros-Lefèbvre, D., \& Steele, J. (2005). Atypical parkinsonism on Guadeloupe, comparison with the parkinsonism - Dementia complex of Guam, and environmental toxic hypotheses. Environmental Toxicology and Pharmacology, $19,407-413$.

Cavé, A., Cortes, D., Figadère, B., Laurens, A., \& Pettit, G. R. (1997). Acetogenins from Annonaceae. In L. Zeichmeister, W. Herz, R. E. Moore, W. Steglich, \& Ch. Tamm (Eds.), Progress in the chemistry of organic natural products (pp. 81-288). Vienna: Springer.

Champy, P., Escobar-Khondiker, M., Bajin, I., Yamada, E., Lannuzel, A., Laprévote, O. et al. (2008). Atypical parkinsonism induced by Annonaceae: Where are we yet? Planta Medica, 74, SL117.

Champy, P., Féger, J., Gleye, C., Laurens, A., Guérineau, V., Laprévote, O., et al. (2004). Annonacin, a lipophilic inhibitor of mitochondrial complex I, induces nigral and striatal neurodegeneration in rats: Possible relevance for atypical parkinsonism in Guadeloupe. Journal of Neurochemistry, 88(1), 63-69.

Champy, P., Guérineau, V., \& Laprévote, O. (2009). MALDI-TOF MS profiling of Annonaceous acetogenins in Annona muricata products for human consumption. Molecules, 14, 5235-5246.

Champy, P., Melot, A., Guérineau, V., Gleye, C., Höglinger, G. U., Ruberg, M., et al. (2005). Quantification of acetogenins in Annona muricata linked to atypical parkinsonism in Guadeloupe. Movement Disorders, 20(12), 1629-1633.

Champy, P. (2011). Acetogenins from the seeds of the custard apple (Annona squamosa L.) and their health outcomes. In V. R. Preedy, R. R. Watson, \& V. B. Patel (Eds.), Nuts and seeds in health and disease prevention (pp. 429-437). Amsterdam, London: Elsevier.

Derbré, S., Gil, S., Taverna, M., Boursier, C., Nicolas, V., Demey-Thomas, E., et al. (2008). Highly cytotoxic and neurotoxic acetogenins of the Annonaceae: New putative biological targets of squamocin detected by activity-based protein profiling. Bioorganic \& Medicinal Chemistry Letters, 18, 5741-5744.

Derbré, S., Roué, G., Poupon, E., Susin, S. A., \& Hocquemiller, R. (2005). Annonaceous acetogenins: The hydroxyl groups and THF rings are crucial structural elements for targeting the mitochondria, demonstration with the synthesis of fluorescent squamocin analogues. ChemBioChem, 6, 1-4.

Gromek, D., Hocquemiller, R., \& Cavé, A. (1994). Qualitative and quantitative evaluation of Annonaceous acetogenins by high performance liquid chromatography. Phytochemical Analysis, 5, 133-140.

Gu, Z.-M., Zhou, D., Lewis, N. J., Wu, J., Johnson, H. A., McLaughlin, J. L., \& Gordon, J. (1999). Quantitative evaluation of Annonaceous acetogenins in monthly samples of paw paw (Asimina triloba) twigs by liquid chromatography/electrospray ionization/tandem mass spectrometry. Phytochemical Analysis, 10, 32-38.

Höllerhage, M., Matusch, A., Champy, P., Lombès, A., Ruberg, M., Oertel, W. H., \& Höglinger, G. U. (2009). Natural lipophilic inhibitors of mitochondrial complex I are candidate toxins for sporadic neurodegenerative tau pathologies. Experimental Neurology, 220, 133-142.

Hollerhage, M., Rosler, T. W., Berjas, M., Luo, R., Tran, K., Richards, K. M., et al. (2015). Neurotoxicity of dietary supplements from Annonaceae species. International Journal of Toxicology, 34, 543-550.

Lannuzel, A., Höglinger, G. U., Verhaeghe, S., Gire, L., Belson, S., Escobar-Khondiker M., et al. (2007). Atypical Parkinsonism in Guadeloupe: A common risk factor for two closely related phenotypes? Brain, 130, 816-827.

Laprévote, O., \& Das, B. (1994). Structural elucidation of acetogenins from Annonaceae by Fast Atom Bombardment Mass Spectrometry. Tetrahedron, 50, 8479-8490.

Le Ven, J., Schmitz-Afonso, I., Lewin, G., Brunelle, A., Touboul, D., \& Champy, P. (2014). Identification of the environmental neurotoxins Annonaceous acetogenins in an Annona cherimolia Mill. alcoholic beverage using HPLC-ESILTQ-Orbitrap ${ }^{\circledR}$. Journal of Agricultural and Food Chemistry, 62, 8696-8704.

Le Ven, J., Schmitz-Afonso, I., Lewin, G., Laprévote, O., Brunelle, A., Touboul, D., \& Champy, P. (2012). Comprehensive characterization of Annonaceous acetogenins within a complex extract by HPLC-ESI-LTQ-Orbitrap ${ }^{\circledR}$ using postcolumn lithium infusion. Journal of Mass Spectrometry, 47, 1500-1509.

Levine, R. A., Richards, K. M., Tran, K., Luo, R., Thomas, A. L., \& Smith, R. E. (2015). Determination of neurotoxic acetogenins in pawpaw (Asimina triloba) fruit by LC-HRMS. Journal of Agricultural and Food Chemistry, 63, 1053-1056.

Potts, L. F., Luzzio, F. A., Smith, S. C., Hetman, M., Champy, P., \& Litvan, I. (2012). Annonacin in Asimina triloba fruit: Implication for neurotoxicity. Neurotoxicology, 33, 53-58.

Rottscholl, R., Haegele, M., Jainsch, B., Xu, H., Respondek, G., Höllerhage, M., Rösler T. W., Bony, E., Le Ven, J., Guérineau, V., Schmitz-Afonso, I., Champy, P., Oertel, W. H., Yamada, E., \& Höglinger, G. (2016). Chronic consumption of Annona muricata juice triggers and aggravates cerebral tau phosphorylation in wildtype and MAPT transgenic mice. Journal of Neurochemistry, 139(4), 624-639.

Yamada, E. S., Respondek, G., Müssner, S., de Andrade, A., Höllerhage, M., Depienne, C., et al. (2014). Annonacin, a natural lipophilic mitochondrial complex inhibitor, increases phosphorylation of tau in the brain of FTDP-17 transgenic mice. Experimental Neurology, 253, 113-125.

Yang, H., Li, X., Tang, Y., Zhang, N., Chen, J., \& Cai, B. (2009). Supercritical fluid CO extraction and simultaneous determination of eight Annonaceous acetogenins in Annona genus plant seeds by HPLC-DAD method. Journal of Pharmaceutical and Biomedical Analysis, 49, 140-144. 